\title{
Seed yield, incidence of yellow vein mosaic virus and economic viability of okra seed crop as influenced by staggered sowing in South- western Punjab
}

\author{
GURDARSHAN SINGH*, A.P.S. BRAR ${ }^{1}$, B.S. DHILLON ${ }^{1}$ AND TILAK RAJ \\ Krishi Vigyan Kendra, FARIDKOT (PUNJAB) INDIA \\ (Email : Singhgurdarshan77@gmail.com)
}

\begin{abstract}
Investigations were carried out in South-western district of Punjab in Indo-Gangetic plain region during four consecutive years to work out the most suitable sowing time to achieve higher seed yield and comparatively less incidence of yellow vein mosaic virus (YVMV) in okra. The sowing of okra was staggered from May 1 to June 15 at fortnightly interval. The results revealed that seed yield differed significantly with different sowing dates. The highest seed yield was observed in crop sown on May 1, followed by crop sown on May 15 but further delay in sowing to June 15 through May 30 resulted in progressive and significant reduction in seed yield of okra. The higher seed yield under earlier sowing can be ascribed to less incidence of YVMV, which was higher under late sown conditions. The income per rupee investment of okra seed crop was found to be the maximum (5.31) when sown on May 1.
\end{abstract}

Key Words : Okra, Sowing dates, Seed yield, YVMV

View Point Article : Singh, Gurdarshan, Brar, A.P.S., Dhillon, B.S. and Raj, Tilak (2017). Seed yield, incidence of yellow vein mosaic virus and economic viability of okra seed crop as influenced by staggered sowing in South- western Punjab. Internat. J. agric. Sci., 13 (2) : $365-370$, DOI:10.15740/HAS/IJAS/13.2/365-370.

Article History : Received : 28.02.2017; Revised : 01.05.2017; Accepted : 15.05.2017

\footnotetext{
* Author for correspondence:

${ }^{1}$ Department of Agronomy, Punjab Agricultural University, LUDHIANA (PUNJAB) INDIA
} 